Sawala - Jurnal Administrasi Negara

ISSN: 2598-4039 (Online)

ISSN: 2302-2221 (Print)

Volume 9 Number 2 December 2021,
Copyright $@$ 2021, Budiono, Ahmad Robbah.

This is an open access article under the CC-BY

NC-SA license

http://DOI 10.30656/sawala.v9i2.3381

Page 201-212

\title{
ANALISIS KUALITAS PELAYANAN RAWAT INAP PADA PUSKESMAS WINONGAN KABUPATEN PASURUAN \\ Budiono, Ahmad Robbah
}

Sekolah Tinggi Ilmu Administrasi Panglima Sudirman Surabaya

\begin{abstract}
The study was compiled to see and analyze the quality of care services at Winongan Public Health Center, Pasuruan Regency, and to see the factors that affect inpatient services. This research is a qualitative descriptive study by observing data through interviews, documentation, and observation. The informants taken by the researcher were the Head of the Inpatient Division of the Winongan Public Health Center, Pasuruan Regency, Administrative Officers, Nurses and patients and / or their families. In this study, the researcher used 5 public service indicators, namely Tangible, Reliability, Responsiveness, Assurance, and Empathy. The results showed that the total quality of services at Winongan Health Center has been carried out well. This means that the quality of the services provided by the Winongan Health Center is maximized. This can be seen from the results of interviews and data that have been previously described that the Tangible, Reliability, Responsiveness, Assurance, and Empathy indicators. then the implementation of Inpatient services at Winongan Health Center is running well, but still requires improvement in several ways, namely: lack of supplies of medical equipment, linen and household tools, cleanliness of rooms and bathrooms, implementation of actions according to Standard Operating Procedures (SOP) and motto that has been set.
\end{abstract}

\begin{abstract}
Abstrak
Penelitian ini disusun untuk mengetahui dan menganalisis kualitas pelayanan rawat inap pada Puskesmas Winongan Kabupaten Pasuruan, serta untuk mengetahui faktor-faktor yang mempengaruhi pelayanan rawat inap. Penelitian ini merupakan jenis penelitian diskriptif kualitatif dengan pengumpulan data melalui wawancara, dokumentasi, dan observasi. Informan yang diambil oleh peneliti adalah Kepala Bidang Rawat Inap Puskesmas Winongan Kabupaten Pasuruan, Petugas Administrasi, Perawat serta pasien dan/atau keluarga pasien. Dalam penelitian ini Peneliti menggunakan 5 (lima) indicator penilaian Pelayanan Publik, yaitu Tangible, Reliability, Responsiveness, Assurance, dan Empathy. Hasil penelitian diperoleh bahwa Secara keseluruhan kualitas Pelayanan di Puskesmas Winongan sudah terlaksana dengan baik. Ini artinya kualitas dari pelayanan yang diberikan oleh pihak Puskesmas Winongan dilaksanakan dengan maksimal. Hal ini dapat dilihat dari hasil wawancara dan data yang telah dipaparkan sebelumnya bahwa dari indikator Tangible, Reliability, Responsiveness, Assurance, dan Empathy. maka pelaksanaan pelayanan Rawat Inap pada Puskesmas Winongan berjalan dengan baik, tetapi masih memerlukan perbaikan dalam beberapa hal yaitu: persediaan alat kesehatan, linen dan alat rumah tangga yang masih kurang, kebersihan ruangan dan kamar mandi, pelaksaan tindakan sesuai Standar Operasional Prosedur (SOP) dan moto yang telah ditetapkan.
\end{abstract}

Kata Kunci: kualitas pelayanan, tangible, reliability, responsiveness, assurance
Keywords:

service quality, tangible, reliability, responsiveness, assurance, empathy

Article history:

Submission September 072021

Revised October 302021

Accepted November 052021

Published December 012021

Corresponding author

Email:

budiono@stiapas.ac.id 
Sawala - Jurnal Administrasi Negara

ISSN: 2598-4039 (Online)

ISSN: 2302-2221 (Print)

Volume 9 Number 2 December 2021,

Page 201-212
Copyright@ 2021, Budiono, Ahmad Robbah. This is an open access article under the CC-BY

NC-SA license http://DOI 10.30656/sawala.v9i2.3381

\section{PENDAHULUAN}

Pelayanan di bidang kesehatan merupakan salah satu bentuk pelayanan public yang menjadi kebutuhan masyarakat. Jika kita ingin menciptakan manusia yang berkualitas dengan kesehatan yang prima, kita membutuhkan pembangunan yang sehat. Pemerintah berupaya mewujudkan pembangunan kesehatan dengan menyediakan beberapa sarana atau fasilitas kesehatan, salah satunya Puskesmas.

Menurut UU No. 36 tentang pelayanan kesehatan tahun 2009, pelayanan kesehatan merupakan hak asasi manusia yang harus dilaksanakan oleh pemerintah karena kebijakan tersebut merupakan prinsip keadilan, daya tanggap dan efisiensi pelayanan. Untuk mencapai derajat kesehatan masyarakat yang optimal, pemerintah berkewajiban memberikan pelayanan kesehatan yang dibutuhkan masyarakat, yaitu memberikan pelayanan yang memuaskan dan nyaman kepada masyarakat. Sebagai acuan bagi pemerintah kabupaten/kota untuk memberikan setidaknya pelayanan kesehatan yang menjadi hak setiap warga negara, pemerintah menetapkan standar pelayanan minimal bidang kesehatan pada tahun 2016 sesuai dengan Peraturan Menteri Kesehatan Republik Indonesia No.43.

Pusat pelayanan kesehatan masyarakat yang selanjutnya disebut puskesmas adalah organisasi pelayanan kesehatan yang menyelenggarakan upaya kesehatan masyarakat dan kebersihan perorangan tingkat pertama dengan fokus pada upaya promotif dan preventif, serta mencapai derajat kesehatan masyarakat yang setinggi-tingginya di wilayah kerjanya. Dari perspektif sistem pelayanan kesehatan masyarakat Indonesia, Puskesmas merupakan pelopor sistem pelayanan kesehatan Indonesia dalam hal peran dan status puskesmas. Sebagai unit penyelenggara pelayanan kesehatan terkecil, puskesmas diharapkan dapat memberikan pelayanan kesehatan yang terbaik kepada masyarakat (Einurkhayatun et al., 2017). Oleh karena itu, pemerintah berupaya untuk mendukung atau memberikan insentif kepada Puskesmas yang ada agar dapat meningkatkan kualitas pelayanan di setiap Puskesmas. Salah satu daerah yang terus diupayakan peningkatan pelayanan publiknya adalah Kabupaten Pasuruan.

Kabupaten Pasuruan memiliki 33 Puskesmas di dinas kesehatan. Salah satunya adalah Puskesmas. Puskesmas menyediakan berbagai pelayanan kesehatan, yang utama adalah rawat inap. Pelayanan kesehatan rawat inap memberikan pasien pelayanan 24 jam tanpa gangguan, sehingga pasien dapat memiliki persepsi yang baik terhadap pelayanan kesehatan. 
Sawala - Jurnal Administrasi Negara

ISSN: 2598-4039 (Online)

ISSN: 2302-2221 (Print)

Volume 9 Number 2 December 2021, Page 201-212
Copyright@ 2021, Budiono, Ahmad Robbah. This is an open access article under the CC-BY

NC-SA license http://DOI 10.30656/sawala.v9i2.3381

Dengan menjadi andalan pelayanan di Puskesmas, maka pelayanan yang diberikan Puskesmas kepada masyarakat dituntut untuk selalu meningkatkan profesionalitasnya (Apriyani \& Sunarti, 2017), (Mulyati, 2020). Peneliti melakukan obesrvasi awal sebelum penelitian, mendapatkan hasil bahwa ada beberapa aspek dalam pelayanan rawat inap yang perlu untuk diperbaiki. Misalnya sarana dan prasarana ruang rawat inap yang kurang optimal, ketersediaan air bersih dalam kamar mandi yang kurang, dan kurang terjaganya kebersihan ruang rawat inap. Selain itu kurangnya dokter umum sehingga pasien rawat inap sering mengeluhkan dalam pemeriksaan. Oleh karenanya, diperlukan penelitian lebih lanjut tentang kualitas pelayanan rawat inap di puskesmas Winongan untuk memenuhi hak masyarakat dalam pelayanan publik bidang kesehatan.

\section{METODE PENELITIAN}

Penelitian ini menggunakan metode penelitian deskriptif kualitatif, yaitu untuk melukiskan atau menggambarkan keadaan subjek dan objek, baik individu, organisasi, maupun komunitas berdasarkan atas penemuan di lapangan dan terkait dengan konsep teori yang relevan. Penelitian dilakukan di Puskesmas dan melibatkan banyak informan yang sengaja ditugaskan pada subjek yang dianggap menguasai dan mampu memberikan informasi tentang masalah penelitian.

Jenis data yang digunakan dalam penelitian ini adalah data subyek (self-reported data) yang diperoleh dari wawancara dengan orang dalam. Selain itu, jenis data yang digunakan juga merupakan jenis data kualitatif, yaitu data berupa informasi, gambaran umum puskesmas, pelaksanaan, dan informasi lain yang digunakan untuk membahas masalah. Sumber data dalam penelitian ini adalah data mentah. Data utama adalah data dari sumber asli atau langsung dari subyek penelitian (responden), yaitu pegawai Puskesmas dan responden lain yang dibutuhkan dalam proses pendataan.

\section{HASIL DAN PEMBAHASAN}

\section{Kualitas pelayanan rawat inap di Puskesmas Winongan Kabupaten Pasuruan}

Untuk memperoleh penjelasan temuan hasil penelitian tentang kualitas layanan dapat dijelaskan berdasarkan indikator kinerja pelayanan (Prakoso et al., 2017) sebagai berikut:

\section{a. Ketampakan Fisik (Tangibles)}

Dilihat dari aspek tangible bahwasannya kemampuan puskesmas dalam menunjukan ekistensinya kepada eksternal, penampilan dan kemampuan sarana dan 
Sawala - Jurnal Administrasi Negara

ISSN: 2598-4039 (Online)

ISSN: 2302-2221 (Print)

Volume 9 Number 2 December 2021, Page 201-212
Copyright@ 2021, Budiono, Ahmad Robbah. This is an open access article under the CC-BY

NC-SA license http://DOI 10.30656/sawala.v9i2.3381

prasarana fisik dan keadaan ligkungan sekitarnya adalah bukti nyata dari pelayanan yang diberikan oleh para petugas Puskesmas dalam melayani masyarakat atau pasien yang dirawat diruang rawat inap. Untuk itu dapat dilihat melalui pernyataan/jawaban beberapa pasien/keluarga pasien (informan) kepada peneliti pada saat peneliti melakukan wawancara dan observasi dilapangan.

Berdasarkan hasil observasi yang penulis lakukan di ruang rawat inap diketahui bahwa kondisi Gedung sangat baik karena gedung untuk ruang rawat inap masih baru dibangun dan kondisinya masih bagus. Jumlah ruang rawat inap ada 12 ruang, terbagi menjadi 3 (tiga), 4 (empat) ruang untuk anak - anak, 4 (empat) ruang untuk pasien perempuan, dan 4 (empat) ruang untuk pasien laki - laki. Setiap ruang memiliki 12 tempat tidur. Kebersihan ruangan cukup terjaga dengan baik hanya saja tidak tersedianya tempat sampah di dalam ruangan maupun di kamar mandi, ada beberapa kasur/tempat tidur di ruangan pasien laki - laki yang sudah kurang layak pakai, tentunya hal tersebut sedikit mengganggu kenyamanan pasien. Hal lain yang kurang dari ruang rawat inap di Puskesmas adalah tidak adanya tempat duduk untuk penunggu atau keluarga pasien. Jadi untuk keluarga pasien harus membawa tikar sendiri untuk menunggu pasien yang sakit. Selain itu, ketersediaan air juga menjadi permasalahan yang ada saat ini.

Permasalahan kebersihan dan air merupakan permasalahan yang cukup vital terhadap pemberian pelayanan kesehatan dan kenyamanan pasien di ruang rawat inap. Selain itu fasilitas sarana dan prasarana yang tersedia di ruang rawat inap terlihat sudah cukup lengkap, meskipun jumlahnya dapat dikatakan masih kurang. Namun sudah memenuhi standar kualitas dan kebutuhan pasien. Ketersediaan peralatan linen dan alat rumah tangga di ruang perawatan dinilai sudah cukup baik, meskipun perlu ditambah lagi sebagai cadangan ruangan karena ada alat yang kurang layak pakai dan perlu diganti.

Indikator tangible (ketampakan fisik) merupakan penilaian terhadap fasilitas fisik, peralatan, personil dan komuniksi. Kondisi bangunan ruang rawat inap yang ada di puskesmas sudah baik namun tetap memerlukan perawatan setiap harinya agar tetap dalam kondisi yang bersih, nyaman dan dapat memenuhi kebutuhan pasien. Tiap ruangan tidak ada pembeda dalam segi fasilitas, semua dipimpin oleh 1 (satu) orang pimpinan kepala bidang rawat inap. 
Sawala - Jurnal Administrasi Negara

ISSN: 2598-4039 (Online)

ISSN: 2302-2221 (Print)

Volume 9 Number 2 December 2021, Page 201-212
Copyright@ 2021, Budiono, Ahmad Robbah. This is an open access article under the CC-BY

NC-SA license http://DOI 10.30656/sawala.v9i2.3381

\section{b. Reliabilitas (Reliability)}

Kualitas pelayan dalam dimensi reliability merupakan kemampuan organisasi untuk memberikan pelayanan yang dijanjikan dengan akurat dan terpercaya (Zalatar, 2017). Ini berarti kinerja Dokter maupun pegawai/perawat Puskesmas harus sesuai dengan harapan masyarakat yang berkaitan dengan ketetapan waktu, pelayanan yang sama untuk semua masyarakat atau pasien dan tanpa kesalahan.

Berdasarkan wawancara dan observasi yang dilakukan penulis diperoleh hasil bahwa pada umumnya perawat/ karyawan yang bekerja sudah memiliki uraian tugas secara tertulis, meskipun dalam pelaksanaannya masih ada saja yang tidak menyadari tugas pokoknya. Sebenarnya didalam struktur organisasi ruang perawatan, perawat tidak hanya bertanggung jawab terhadap asuhan keperawatan saja tetapi juga diberikan tanggung jawab mengelola administrasi surat menyurat yang berhubungan dengan perawat dan pasien pulang, serta juga bertanggung jawab terhadap kebersihan ruangan. Permasalahan yang menjadi keluhan beberapa pasien maupun keluarga pasien yaitu pelayanan khususnya pada malam hari ada beberapa pegawai puskesmas yang jarang mengkontrol pasien, hal ini tentunya kurang memenuhi kebutuhan pasien.

Didalam standar untuk Rawat Inap, telah ditetapkan segala sesuatu yang harus dilakukan dan kapan harus dilaksanakan. Dan pelayanan harus tidak boleh melanggar dari standar yang telah ditetapkan tersebut. Dari hasil waancara dengan informan penelitian diatas, maka pelayanan keperawatan sudah dilaksanakan dengan cukup baik, meskipun kurang maksimal terkait kedisiplinan dari masing - masing petugas dalam mengatur waktu khususnya di shift malam.

Di shift malam perawat jarang mengkontrol pasien dikarenakan belum adanya masalah ataupun keluhan dari pasien rawat inap Puskesmas. Hal ini secara jelas telah menunjukkan bahwa perawat untuk rawat inap belum mampu mentaati peraturan atau SOP yang telah di tetapkan sehingga pelayanan belum berjalan sesuai dengan yang diinginkan.

Menurut Yaslis Ilyas (2011), produk Puskesmas berbentuk jasa yang dapat dinikmati dengan segera oleh pasien, maka kualitas layanan menjadi sangat penting. Peran SDM Puskesmas sangat penting dalam menentukan kualitas jasa Puskesmas baik yang berbentuk medis non medis, maupun penunjang. Dengan demikian, kualitas dan kuantitas SDM Puskesmas berperan secara kritis dalam meningkatkan dan menjaga kualitas pelayanan kesehatan, sehingga harus direncanakan dengan sebaik - baiknya. 
Sawala - Jurnal Administrasi Negara

ISSN: 2598-4039 (Online)

ISSN: 2302-2221 (Print)

Volume 9 Number 2 December 2021, Page 201-212
Copyright@ 2021, Budiono, Ahmad Robbah. This is an open access article under the CC-BY

NC-SA license http://DOI 10.30656/sawala.v9i2.3381

Pengelolaan SDM yang terdiri dari berbagai macam profesi memang lebih sulit dibandingkan hanya terdiri dari 1 - 2 jenis profesi saja. Selain berbeda jenis profesi, faktor kuantitas juga menjadi permasalahan lain lagi. Menurut Yaslis Ilyas (2011), bahwa perencanaan ketenagaan Puskemas harus benar, terutama untuk menjaga kontinuitas tenaga dengan baik. Suatu hal yang perlu dilakukan oleh manajemen adalah bagaimana membuat personel loyal terhadap organisasi.

Selain perencanaan SDM yang akurat maka program penggajian dan pengembangan karier perlu diperhatikan dengan seksama agar memberikan kepuasan kerja yang ada pada akhirnya menimbulkan loyalitas SDM terhadap organisasi.

\section{c. Daya Tanggap (Responsiveness)}

Responsivness adalah kemampuan daya tanggap dalam memberikan pelayanan. Dimana pelayanan itu diberikan dengan cepat dan tepat. Pegawai mampu menanggapi keluhan pasien dan cepat dalam mengambil tindakan untuk mengatasi atau paling tidak mengurangi peluang makin buruknya keadaan pasien (Speer, 2012). Semakin cepat keluhan pasien dapat ditangani maka akan semakin baik pula tingkat kualitas pelayanan yang telah diberikan kepada pihak Puskesmas terhadap Pasien. Begitu pula sebaliknya, jika semakin lambat keluhan pasien ditanggapi dan diatasi, maka semakin buruk pula kualitas pelayanan Puskesmas. Hal ini didukung oleh Aminullah (2018) dalam penelitian yang menyebutkan bahwa responsiveness adalah suatu kebijakan untuk membantu dan memberikan pelayanan yang cepat (responsif) dan tepat kepada pelanggan, dengan penyampaian informasi yang jelas.

Berdasarkan observasi yang dilakukukan oleh penulis penulis dilapangan memberikan gambaran bahwa petugas baik dalam merespon pasien, petugas memberikan informasi tentang pelayanan yang akan diberikan kepada pasien, petugas menemui atau mengunjungi pasien, meskipun pada saat - tertentu khususnya shift malam ada beberapa petugas yang kurang respon dalam pelayanan. Hal ini sejalan dengan tanggapan dari pihak puskesmas, yakni perawat dan petugas yang diwawancarai, mereka menganggap hal tersebut memang pun kalau ada petugas yang kurang merespon terhadap keluhan pasien atau jarang mengunjugi pasien saat shift malam itu hanya sebagian kecil saja.

Namun secara umum pasien merasakan puas dengan pelayanan yang dilakukan oleh perawat/petugas puskesmas. Pasien memahami hal itu karena mungkin perawat perawat disini mempunyai kesibukan yang harus diselesaikan setiap harinya. 
Sawala - Jurnal Administrasi Negara

ISSN: 2598-4039 (Online)

ISSN: 2302-2221 (Print)

Volume 9 Number 2 December 2021, Page 201-212
Copyright@ 2021, Budiono, Ahmad Robbah. This is an open access article under the CC-BY

NC-SA license http://DOI 10.30656/sawala.v9i2.3381

Aspek responsiveness dapat peneliti interpretasikan sesuai dengan teori yang ada, memang Pusksesmas yang responsive adalah puskesmas yang melakukan segala upaya untuk mengenali, melayani dan memuaskan kebutuhan dan kenginan pasien/klien dan publiknya. Oleh karena itu setiap puskesmas dapat mengukur seberapa responsifkah dirinya serta menetapkan bagimana menngkatkan kemampuannya untuk menciptakan kepuasan pasien/klien.

Berdasarkan data yang didapat jika dikaitkan dengan teori yang ada, dapat disimpulkan bahwa berkaitan dengan aspek responsiveness kualitas pelayanan rawat inap pada puskesmas dapat dikatakan sudah baik, hal ini dikarenakan selama observasi dan hasil wawancara kepada pasien tergambar bahwa kemauan pegawai untuk membantu dan memberikan jasa pelayanan dilakukan dengan cepat, tepat dan tanggap. Meskipun masih ada 1 - 2 pegawai yang masih kurang tanggap pada jam - jam tertentu khususnya di shift malam, dan hal itu perlu dievaluasi dan ditindaklanjuti oleh kepala ruang rawat inap ataupun kepala puskesmas.

\section{d. Jaminan (Asurance)}

Kualitas pelayanan dilihat dari aspek asurance adalah jaminan dan kepastian yang berupa pengetahuan kesopan santunan, kesabaran, keramahan dan murah senyum serta kemampuan pegawai puskesmas dalam melaksanakan tugas yang dapat menjamin kinerja yang baik sehingga menimbulkan kepercayaan dan keyakinan pasien serta bebas dari keragu-raguan terhadap puskesmas. Semakin baik kinerja dari perawat, dokter, maupun pegawai lainnya maka akan semakin tinggi terjamin tingkat kepercayaan pasien dan masyarakat terhadap Puskesmas. Aspek assurance meliputi beberapa komponen antara lain komunkasi, kredibilitas, keamanan, kompetensi dan sopan santun.

Berdasarkan wawancara dan observasi yang dilakukan penulis dinilai dari indicator Asurance, Kualitas Pelayanan Rawat Inap di puskesmas dinilai sudah baik, sebagian besar pegawai di puskesmas sangat ramah dan sabar dalam memberikan pelayanan kepada pasien, meskipun masih ada $1-2$ orang yang masih perlu pembinaan dari kepala ruang rawat inap atau atasan selanjutnya.

Moto 5S yaitu senyum, salam, sapa, sopan, santun yang menjadi jaminan etika dalam pemberian pelayanan sudah terlaksana dengan baik, meskipun masih ada beberapa petugas yang kurang melaksanakan motto tersebut dalam melaksanakan tugas. Hal ini dapat dikatakan baik karena tegasnya sikap pimpinan atau kepala Puskesmas terhadap anggotanya sehingga dapat terlaksana dengan baik. Karena, 
Sawala - Jurnal Administrasi Negara

ISSN: 2598-4039 (Online)

ISSN: 2302-2221 (Print)

Volume 9 Number 2 December 2021, Page 201-212
Copyright@ 2021, Budiono, Ahmad Robbah. This is an open access article under the CC-BY

NC-SA license http://DOI 10.30656/sawala.v9i2.3381

keramahan dan kesopanan dalam memberikan pelayanan khususnya pelayanan terhadap pasien itu sangat diperlukan sekali karena dengan pelayanan yang ramah dan sopan maka pasien pun akan mendapat kenyamanan dari pelayanan yang diberikan.

Permasalahan ini memang tidak melibatkan semua, tapi biasanya kejelekan yang ditunjukkna oleh satu orang dapat menghilangkan kebaikan dari yang lainnya dan mempengaruhi kepercayaan pasien nantinya. Jadi pendapat yang mengatakan perawat masih ada yang kurang ramah perlu dievaluasi ulang. Hal ini mungkin dilakukan $1-2$ orang saja tetapi disamakan untuk semua perawat/pegawai yang bertugas pada ruang rawat inap.

Berkaitan dengan pernyataan Parasuraman, Zeithaml dan Berry dalam Pasolong (2010) dimensi-dimensi yang mewakili persepsi konsumen terhadap suatu kualitas pelayanan jasa termasuk diantaranya adalah aspek assurance, dimana aspek ini adalah dimensi kualitas pelayanan yang berhubungan dengan kemampuan dalam menemukan kepercayaan dan keyakinan kepada konsumen. Dimensi/aspek assurance atau aspek kepastian ini meliputi kemampuan tenaga kerja atas pengetahuan terhadap produk meliputi kemampuan karyawan atas pengetahuan terhadap produk secara tepat, kualitas keramah-tamahan, perhatan dan kesopanan dalam memberi pelayanan, keteramplan dalam memberikan keamanan didalam memanfaatkan jasa yang ditawarkan dan kemampuan didalam menanamkan kepercayaan konsumen terhadap jasa yang ditawarkan, termasuk dsini jasa pelayanan puskesmas. Ini sejalan dengan pendapat Nugroho \& Prawoto (2018) yang menyatakan jaminan adalah pengetahuan, kesopanan dan kemampuan petugas dalam memberikan pelayanan kepada masyarakat sehingga dapat menumbuhkan rasa kepercayaan dan keyakinan masyarakat terhadap keamanan setiap pelayanan yang diberikan.

Kesopanan merupakan sikap atau perilaku ramah, bersahabat, tanggap terhadap keinginan konsumen serta mau melakukan kontak atau hubungan langsung kepada konsumen atau pasien. Berdasarkan Secara keseluruhan memberikan kesimpulan bahwa berkaitan dengan aspek asurance Kualitas Pelayanan Rawat Inap di puskesmas dinilai sudah baik, meskipun masih ada 1 - 2 orang yang masih perlu pembinaan dari kepala ruang rawat inap atau atasan selanjutnya.

\section{e. Empati (Empathy)}

Emphaty yang dimaksudkan disini adalah perhatian pribadi yang diberikan kepada pasien rawat inap Puskesmas. Parasuraman, Zeithaml dan Berry dalam Pasolong (2010) 
Sawala - Jurnal Administrasi Negara

ISSN: 2598-4039 (Online)

ISSN: 2302-2221 (Print)

Volume 9 Number 2 December 2021, Page 201-212
Copyright@ 2021, Budiono, Ahmad Robbah. This is an open access article under the CC-BY

NC-SA license http://DOI 10.30656/sawala.v9i2.3381

mengatakan bahwa salah satu indikator pelayanan dalam dimensi Emphaty adalah petugas melayani dengan tidak diskriminatif (membeda-bedakan). Artinya pihak Puskesmas harus mampu memberikan perhatian pribadi terhadap pasien dengan tanpa memandang status sosial dan sebagainya sehingga semua pasien mendapat perhatian dan perlakuan yang sama didalam mendapatkan pelayanan dari pihak Puskesmas. Empathy merupakan dimensi mutu pelayanan yang meliputi pemahaman pemberian perhatiaan secara individual kepada pelanggan, kemudahan dalam melakukan komunikasi yang baik, dan memahami kebutuhan pelanggan (Ahmed et al., 2017; Lestari \& Nurcahyanto, 2017; Shen, 2015).

Aspek empathy selalu menanyakan keluhan dan masalah pasien, tanggapan petugas terhadap keluhan pasien dan bagaimana petugas bsa mengenali pasien dengan baik. Pelayanan yang empatik sangat memerlukan sentuhan/perasaan pribadi, aspek empathy adalah aspek yang memberikan peluang besar untuk menciptakan pelayanan yang surprise yaitu sesuatu yang tidak diharapkan pasien tetapi ternyata diberikan oleh puskesmas.

Berdasarkan wawancara dan observasi yang dilakukan penulis dinilai dari indicator Empathy, kualitas pelayanan rawat inap pada Puskesmas dinilai sudah baik, sudah memenuhi kebutuhan pasien, tidak membedakan status sosial pasien, selalu menanyakan keluhan pasien dan menanyakan perkembangan pasien yang dirawat diruang rawat inap puskesmas.

Selama melakukan pengumpulan data baik melalui wawancara maupun observasi di ruang rawat inap puskesmas pegawai cukup aktif dalam mengontrol pasien, menanyakan keluahan dan menanyakan perkembangan pasien. Berkaitan dengan pernyataan Parasuman, dimensi - dimensi yang mewakili persepsi konsumen terhadap suatu kualitas pelayanan jasa termasuk di antaranya adalah aspek empathy, dimana aspek ini adalah kesediaan petugas untuk peduli dan memberikan perhatian pribadi kepada pengguna jasa. Pelayanan yang empathy sangat memerlukan sentuhan/perasaan pribadi. Aspek empathy adalah aspek yang memberikan peluang besar untuk menciptakan pelayanan yang surprise yaitu sesuatu yang tidak di harapkan pengguna jasa tetapi tenyata di berikan oleh penyedia jasa. Aspek empathy ini merupakan penggabungan dari aspek:

1) Akses (acces) meliputi kemudahan memanfaatkan jasa yang di tawarkan penyedia jasa. 
Sawala - Jurnal Administrasi Negara

ISSN: 2598-4039 (Online)

ISSN: 2302-2221 (Print)

Volume 9 Number 2 December 2021, Page 201-212
Copyright@ 2021, Budiono, Ahmad Robbah. This is an open access article under the CC-BY

NC-SA license http://DOI 10.30656/sawala.v9i2.3381

2) Komunikasi (comunication) yaitu merupakan kemampuan melakukan komunikasi untuk menyampaikan informasi kepada konsumen atau memperoleh masukan dari konsumen

3) Pemahaman pada konsumen (anderstanding the customer,) meliputi usaha penyedia jasa untuk mengetahui dan memahami kebutuhan dan keinginan konsumen.

Berkaitan dengan pelayanan kesehatan menurut Azwar (2010) serta didukung oleh Muslimin \& Nurhayati (2018) menyatakan bahwa batasan dalam kesehatan yang bermutu adalah pelayanan kesehatan yang dapat memuaskan setiap pemakai jasa sesuaii dengan tingkat kepuasan rata-rata penduduk, serta penyelenggaraannya sesuai kode etik dan standar yang telah di tetapkan. Kualitas pelayanan kesehatan di puskesmas merupakan suatu fenomena unik, sebab aspek dan indikatornya dapat berbeda di antara orang-orang yang terlibat dalam pelayanan kesehatan.

Secara keseluruhan memberikan kesimpulan bahwa berkaitan dengan aspek empathy kualitas pelayanan rawat inap pada Puskesmas dinilai sudah baik, sudah memenuhi kebutuhan pasien, tidak membedakan status sosial pasien, selalu menanyakan keluhan pasien dan menanyakan perkembangan pasien yang dirawat diruang rawat inap puskesmas.

\section{Faktor-faktor yang mempengaruhi pelayanan rawat inap pada Puskesmas Winongan}

Kualitas pelayanan publik yang diberikan oleh suatu organisasi dipengaruhi oleh berbagai faktor, seperti perilaku pegawai, ketegasan pemimpin, sarana dan prasarana yang digunakan untuk proses pelayanan dan sebagainya. Apabila manajemen ingin menciptakan sebuah layanan yang bermutu, maka pengajuan permintaan barang dari unit - unit pelayanan tidak bisa diabaikan begitu saja karena dapat mempengaruhi kemampuan pegawai dalam memberikan pelayanan kepada pasien. Saat ini kebutuhan pasien menjadi perioritas utama pegawai kesehatan yang bekerja di puskesmas, tidak lagi mengarah kepada kepntingan pribadi melainkan kepentingan pasien.

Pada Puskesmas ditemukan beberapa faktor yang mempengaruhi kualitas pelayanan rawat inap berdasarkan hasil temuan penulis selama pengumpulan data yang dilakukan pada ruangan rawat inap. Adapun faktor - faktor tersebut antara lain:

a. Perilaku pegawai, faktor kesadaran sangat mempengaruhi kinerja pegawai dalam menjalankan tugas pokok dan fungsinya masing - masing yang akan be rdampak positif bagi kinerja individu maupun organisai sehingga pencapaian terhadap visi 
Sawala - Jurnal Administrasi Negara

ISSN: 2598-4039 (Online)

ISSN: 2302-2221 (Print)

Volume 9 Number 2 December 2021, Page 201-212
Copyright@ 2021, Budiono, Ahmad Robbah. This is an open access article under the CC-BY

NC-SA license http://DOI 10.30656/sawala.v9i2.3381

dan misi serta tujuan organisasi akan mejadi optimal dan sesuai dengan standar yang telah ditetapkan.

b. Ketegasan pemimpin, ketegasan dari seorang pemimpin diharapkan Puskesmas akan memiliki pegawai yang displin terhadap tugas dan aturan, pelaksanaa fungsi pengawasan terhadap kinerja pegawai masih memerlukan motivasi dari pemimpin. Seharusnya peran dan fungsi ini sudah menjadi tuposi para pejabat struktural, tapi pada kenyataannya belum maksimal dilakukan

c. Fasilitas sarana dan prasarana Puskesmas, fasilitas merupakan salah satu faktor penunjang dalam menunjang pelayanan, Puskesmas harus bisa melengkapi sarana dan prasarana khususnya alat-alat medis. Sejauh ini fasilitas yang ada memang sudah cukup lengkap, namun masih ada beberapa kekurangan seperti alat ronson dan alatalat penting lainnya.

\section{PENUTUP}

Dari hasil peneletian ini disimpulkan sebagaimana unusr pelayanan dalam aspek tangible, reliability, responsiveness, asurance, empathy Dipengaruhi oleh factor perilaku pegawai, faktor kesadaran pegawai dalam menjalankan tugas pokok dan fungsinya sebagaimana fungsi masing-masing. Selajutnya factor Ketegasan pemimpin, ketegasan dari seseorang pemimpin diharapkan

Selajutnya factor fasilitas sarana dan prasarana Puskesmas, fasilitas merupakan salah satu faktor penunjang dalam menunjang pelayanan dan upaya - upaya yang dapat dilakukan oleh Puskesmas Winongan dalam menentukan keberhasilan kualitas rawat inap secara garis besarnya adalah: profrsionalisme, faktor kepemimpinan, fokus kepada pelanggan, dan penilaian kinerja staf.

\section{REFERENSI}

Ahmed, S., Tarique, K. M., \& Arif, I. (2017). Service quality, patient satisfaction and loyalty in the Bangladesh healthcare sector. International Journal of Health Care Quality Assurance.

Aminullah. (2018). Analisis Tingkat Harapan dan Kepuasan Terhadap Kualitas Pelayanan Penyelenggaraan Diklat Teknis Fungsional Guru Tingkat Madya IPS Madrasah Tsanawiyah. Andragogi: Jurnal Diklat Teknis Pendidikan Dan Keagamaan, $6(2), 1-45$. 
Sawala - Jurnal Administrasi Negara

ISSN: 2598-4039 (Online)

ISSN: 2302-2221 (Print)

Volume 9 Number 2 December 2021, Page 201-212
Copyright@ 2021, Budiono, Ahmad Robbah. This is an open access article under the CC-BY

NC-SA license http://DOI 10.30656/sawala.v9i2.3381

Apriyani, D. A., \& Sunarti, S. (2017). Pengaruh Kualitas Pelayanan Terhadap Kepuasan Konsumen (Survei Pada Konsumen the Little a Coffee Shop Sidoarjo). Jurnal Administrasi Bisnis, 51(2), 1-7.

Azwar, A. (2010). Pengantar Administrasi Kesehatan. Binarupa Aksara Publisher.

Einurkhayatun, B., Suryoputro, A., \& Fatmasari, E. Y. (2017). Analisis Tingkat Kepuasan Pasien Terhadap Kualitas Pelayanan Rawat Jalan di Puskesmas Duren dan Puskesmas Bergas Kabupaten Semarang Tahun 2017. Jurnal Kesehatan Masyarakat (eJournal), 5(4), 33-42.

Ilyas, Y. (2011). Perencanaan SDM Rumah Sakit, Teori, Metoda, dan Formula. In Cetakan Ketiga. FKM UI.

Lestari, Y., \& Nurcahyanto, H. (2017). Analisis tingkat kepuasan pasien rawat jalan (Studi kasus pada pasien rawat jalan di RSUD Dr. M. Ashari Kabupaten Pemalang). Journal of Public Policy and Management Review, 6(2), 441-454.

Mulyati, L. (2020). Hubungan Kualitas Pelayanan Rawat Inap Dengan Indeks Kepuasan Masyarakat Puskesmas Wonosari. Jurnal Keperawatan Profesional, 8(2), 16-23.

Muslimin, I., \& Nurhayati, N. (2018). Daya Tanggap Kualitas Pelayanan Perawat Pasien Rawat Inap Bedah di RSUD Labuang Baji. Jurnal Kesehatan Manarang, 2(1), 57-60.

Nugroho, W., \& Prawoto, M. A. (2018). Analisis Kepuasan Peserta Terhadap Kualitas Pelayanan Widyaiswara Pada DTSS Pengadaan Barang/Jasa di BDK Malang. Jurnal Pendidikan Nonformal, 12(2), 62-76.

Pasolong, H. (2010). Kepemimpinan Birokrasi. Alfabeta.

Prakoso, A., Kurniawan, R., Marlena, N., Hakim, L., Dewi, R., Widayati, I., Solichin, M., Andriansyah, E., Abdul Ghofur, M., Fitrayati, D., Rachmawati, L., Sholikhah, N., Trisnawati, N., Wulandari, R., \& Soesatyo, Y. (2017). Reliability, Responsiveness, Assurance, Empathy, and Tangible: still can satisfy the customer? International Journal of Business and Management Invention, 6, 68-75.

Shen, L. (2015). Targeting smokers with empathy appeal antismoking public service announcements: a field experiment. Journal of Health Communication, 20(5), 573-580.

Speer, J. (2012). Participatory governance reform: a good strategy for increasing government responsiveness and improving public services? World Development, 40(12), 2379-2398.

Zalatar, W. F. (2017). Service Quality and Customer Satisfaction in Fast Food Restaurants: A Customer Comparison Using Discriminant Analysis. DLSU Research Congress. 